\title{
TVORBA A VIZUALIZÁCIA 3D MAPY PRIEMYSELNÉHO ZÁVODU
}

CREATION AND VISUALIZATION OF 3D MAPS OF INDUSTRIAL ENTERPRISE

Ing. J án J ežko, Ph.D.

\section{ABSTRAKT}

Ciel’om príspevku je priblížit' programové prostriedky vhodné na tvorbu účelovej digitálnej mapy. Stručne je popisovaný grafický systém MicroStation, KOKEŠ, podrobnejšie softvér ATLAS a Atlas DMT, vrátane jeho základných vlastnosti, rozširujúcich modulov a samotnej tvorby 3D modelu a jeho vizualizácie na príklade účelovej digitálnej mapy závodu.

Klíčová slova: Digitálna mapa, programové prostriedky pre tvorbu grafiky, tvorba 3D modelu.

\section{ABSTRACT}

The aim of the article is approach of the software suitable for the specific digital map creation. Briefly the graphic software MicroStation and KOKEŠ are described, more detailed the software ATLAS and Atlas DMT, including its basic attributes, expansion modules and straight creation of 3D model and its visualization in the example of creation a specific digital map of enterprise.

Key words: Digital map, program tools for creating graphics, 3D modeling.

\section{1 ÚVOD}

\subsection{Grafický systém MicroStation}

Program patrí do skupiny grafických programov označovaných ako „CAD“ programy (Computer Aided Design). Svojimi vlastnostami sa program MicroStation radí do kategórie programovatel'ných graficko-informačných systémov pracujúcich v rovine aj v priestore. Jeho použitie je vel'mi široké od elektrotechniky, strojárenstva cez stavebníctvo, architektúru, až po mapovanie, geodéziu a geograficko-informačné systémy (GIS), všade tam, kde je nutné vytvárat' grafickú technickú dokumentáciu.

Program MicroStation umožňuje vytvárat' výkresy pomocou základných prvkov (entít) ako sú čiary, body, oblúky, kružnice, krivky a multičiary. Tieto prvky umožňuje kombinovat' do zložitejších štruktúr, modifikovat' ich, kopírovat', premiestňovat', otáčat', umožňuje takto vytvorené prvky združovat' do užívatel'ských knižníc prvkov, a iné.

Ďalšími dôležitými vlastnost’ami tohto programu je možnost' spájania grafických informácií výkresu s textovými údajmi, čo umožňuje vytvorenie si vlastného GIS, ako aj možnost' dopĺn̆at základné prostredie programu o d'alšie komponenty za pomoci programovacích jazykov MicroStation Basic, MDL (MicroStation Development Language), JMDL (Java MDL). Aplikácie vytvorené týmito programovacími jazykmi sa stávajú súčastou MicroStationu a umožňujú užšiu špecializáciu, či využitie programu. Sú to napríklad: Mkataster, aplikácia na komplexné riešenie ROEP (register obnovenej evidencie pozemkov) v rámci katastrálnych území, d’alej Groma, aplikácia výpočtových 
geodetických úloh v prostredí programu MicroStation, či Geo, aplikácia určená na tvorbu geometrických plánov [1].

\subsection{Grafický systém KOKEŠ}

Systém KOKEŠ, je interakčný grafický systém užívatel'sky orientovaný na odbor geodézie a na geoinformačné systémy. Umožňuje riešenie rôznych geodetických a konštrukčných výpočtov, vytváranie a aktualizáciu kresby máp, vedenie popisných údajov k objektom a bodom mapy, digitalizáciu grafických podkladov, grafické a tlačové výstupy na plotery a tlačiarne. Je prepojený s d’alšími geodetickými, grafickými a databázovými systémami.

Vo svojich výpočtových nástrojoch má obsiahnutú celú škálu bežných geodetických výpočtových riešení. Medzi základné dátové množiny systému KOKEŠ patrí okrem zoznamu súradníc a rastra aj výkres. Výkres obsahuje vektorové dáta, mapu alebo jej čast'. Vedl'a grafických dát - bodov, línií a textov - môže výkres obsahovat' atribúty, textové elementy a líniové elementy.

K základnému prostrediu systému je možné pripojit’ viaceré nadstavby, špecificky zamerané na užšiu problematiku prevažne geodetických riešení, napríklad nadstavbu na tvorbu vektorovej katastrálnej mapy (VKM), na tvorbu geometrických plánov, na tvorbu registrov obnovenej evidencie pozemkov (ROEP), či na prepojenie systému KOKEŠ so softvérovým prostredím programu ATLAS určeného na tvorbu vrstevníc a digitálnych modelov terénu.

\subsection{Softvér ATLAS}

\subsubsection{Program KRES}

Hlavným účelom programu Kres je poskytnút' grafické prostredie pre tvorbu grafických aplikácií a výstupov nad digitálnym modelom terénu (DTM) Atlas. V programe Kres možno vytvárat' grafické dokumenty (výkresy) obsahujúce vektorovú aj rastrovú kresbu.

Všetky objekty v dokumente sú organizované v stromovej štruktúre, podobnej štruktúre adresárov (zložiek) na disku počítača. Stromová štruktúra poskytuje možnost’ určenia súradnicovej sústavy (príp. skupiny súradnicových sústav) pre svoje ,podobjekty". To umožňuje napr. pri rozmiestnení viac rezov a pôdorysov na jednom liste pracovat' striedavo na l'ubovol'nom z týchto objektov vždy v správnej súradnicovej sústave bez nutnosti akéhokol'vek prepínania, či jednoduché premiestňovanie objektov so všetkými pripojenými podobjektami. Ďalšou vlastnost'ou stromovej štruktúry je to, že podobjekty môžu prijímat' grafické vlastnosti (farbu čiary a pod.) od objektov, ku ktorým sú pripojené.

Program podporuje aj systém pomenovaných hladín, ktorých môžeme vytvorit' aj niekol'ko tisíc a objekty do nich zarad'ovat' nezávisle na stromovej štruktúre. Hladiny môžu tiež určovat' grafické vlastnosti objektov. Objekty možno rozdelit' na obecné, ktorými sú napr. úsečky, oblúky, krivky, texty, obdĺžniky a pod., a objekty význačné či aplikačné, ktorých vlastnosti sú dané ich zvláštnym určením. Väčšinou sú už výsledkom nadstavbových aplikácií. Takými objektmi sú napríklad pôdorys, model terénu či zostava rezov [3].

\subsubsection{Atlas DMT}

Atlas DMT je základné prevedenie softvéru Atlas, obsahuje vlastný kresliaci program (grafický editor). Okrem špeciálnych funkcií týkajúcich sa DMT je možné ho použit’ aj na bežné kreslenie úsečky, polygóny, výplne, šrafy, typy čiar a pod.. 
Hlavným účelom programu Atlas DMT je tvorba, upravovanie digitálnych modelov terénu (DMT) a vytváranie grafických výstupov nad nimi [4].

Dôležitou častou je programové prostredie, ktoré umožňuje rýchly a efektívny vývoj nadstavbových aplikácií nad digitálnym modelom, alebo bez neho. Možno ho považovat' za aplikáciu CAD, ktorá poskytuje niektoré služby nedostupné v iných grafických systémoch.

\subsubsection{Základné vlastnosti digitálneho modelu terénu Atlas DMT}

Dôležitou vlastnost’ou softvéru je čítanie zoznamu bodov (x, y, z), prípadne lomových hrán z najrôznejších zdrojov, ako sú:

- geodetické merania,

- fotogrametria - údaje z leteckých družicových snímok,

- digitalizácia máp - pomocou tabletu, z naskenovaného rastru priamo na obrazovke,

- využitie vektorizovaných vrstevníc,

- import DXF súborov z CAD a GIS programov,

- možnost' dávkového načítania bodov do hotového modelu.

Atlas DMT umožňuje spracovanie vel'mi rozsiahlych dát (až 10 miliónov bodov). Špeciálne vyvinuté algoritmy pracujú priamo shladkou plochou - nedochádza teda k dodatočnému vyhladzovaniu a k nepresnostiam z neho vyplývajúcich, výhodou je teda :

- rýchle vytvorenie plochy i spracovanie rozsiahlych údajov,

- práca s nepravidelnou trojuholníkovou siet’ou,

- možnost' definovat' 5 typov lomových hrán,

- podpora rôznych súradnicových systémov, vrátane systému JTSK a Gauss-Krüger,

- funkcia na výškovú generalizáciu plochy ( vypustenie „nadbytočných“ bodov môže výrazne zredukovat' vel'kost' modelu a tým zefektívnit' prácu).

Interaktívny grafický editor plochy umožňuje rýchlu a komfortnú prácu s modelmi:

- rýchla kontrola vstupných dát, možnost' interaktívnej opravy bez nového generovania modelu,

- možnost' modelovania a úprav terénu priamo na obrazovke,

- okamžitá kontrola priebehu reliéfu pomocou vrstevníc, profilov a d’alších informácií [4].

Okrem toho, systém poskytuje d’alšie nástroje pre prácu s plochou, ako porovnávanie, sčítanie, odčítanie a prelínanie dvoch plôch, práca s oblast'ou v modely, prenos do iného modelu, zhustenie či zriedenie bodového pol’a a transformácia (afinná, podobnostná, identické body).

\subsubsection{Rozširujúce moduly}

K základnému prevedeniu softvéru Atlas je možné si zaobstarat' rozširujúce moduly. Existuje pät' rozširujúcich modulov, a to FOTO, DESIGN, ŤAŽBA, OBJEM, REZY, GENERAL, 3D RASTER a 3D OBJEKTY a aplikácie TOK, CESTY, KANAL, VODA, PLYN, ERÓZIA, ŤAŽBA a d’alšie.

\section{$\underline{\text { FOTO }}$}

Modul Foto rozširuje možnosti použitia DMT o prácu s rastrami v pôdoryse, rýchly 3D pohl’ad na model a vizualizáciu, vrátane mapovania rastrov na 3D povrchu, hmlu, animáciu a d'alšie funkcie. 3D 
náhl'ad na model a vizualizáciu obstaráva modul 3D RASTER. Ten je súčast'ou rozšírenia Foto a umožňuje rýchly perspektívny pohl’ad na model a vytváranie vizualizačných vstupov.

\section{DESIGN}

Obsahuje sadu nástrojov pre vyňatie časti DMT (oblasti), jej editáciu a upravovanie mimo pôvodný "vel'ký" model a následné vrátenie na pôvodné miesto. Tieto nástroje umožňujú i "prepísanie" časti DMT novým modelom, získaným bud' novým meraním alebo projektom. Umožňuje výpočet rozdielového modelu medzi dvoma plochami - napr. pri terénnych úpravách a jeho znázornenie $\mathrm{v}$ situácii napr. farebnou škálou (výkopy, navážky). Jeho súčastou je i funkcia pre vyhladenie terénu pri "neučesaných" údajoch, ktoré vznikajú napr. z fotogrametrie, je možné potlačit' lokálne nerovnosti.

ড̌Ǎ̌BA

Je to špeciálne prevedenie pre t’ažobnú činnost', a to výpočty objemu vrstiev a plánovanie t'ažby.

$\underline{\text { REZY }}$

Modul obsahuje najrôznejšie spôsoby generovania pozdížnych a osových priečnych rezov nad zadaným polygónom, ich rozmiestnenie, popis a editáciu. Umožňuje prispôsobit' výkresy rezov požiadavkám najrôznejších profesií a spracovávat' v jednom dokumente pôdorys i rezy so zachovaním všetkých vzájomných väzieb. Rezy a profily sú dynamicky prepojené s polygónom, čo znamená, že pri zmene jeho vedenia sa rezy automaticky prepočítajú.

\section{$\underline{\text { OBJEM }}$}

Počíta kubatúry medzi dvoma plochami (DMT), typicky medzi zameraním starého a nového stavu alebo zameraním a projektom.

\section{GENERAL}

Je to modul pre generalizáciu - znižuje počet bodov výškopisu podl’a zadanej výškovej tolerancie. Je vhodný najmä pre spracovanie rozsiahlych dát z fotogrametrie a vektorizovaných vrstevníc. Pri DMT vzniknutých z vektorizovaných vrstevníc sa prejavujú typické chyby - terasy na hrebeňoch a kaskády v údoliach. General vie tieto chyby rozoznat' a odstránit'.

\section{D RASTER a 3D OBJEKTY}

3D Raster a 3D Objekty slúžia na rýchly perspektívny pohl'ad na model a na vytváranie statických a dynamických vizualizácií terénu.

3D Raster je výstupný modul pre znázornenie plochy pomocou trojuholníkovej siete, hrán, vrstevníc, šrafovaní, plôšok a osvetlením, farebnej hypsometrie a sklonov, to všetko vrátane animácie pohl'adov vo formáte AVI. Je tu i možnost' zobrazenia rastrových dát (mapa, ortofoto) v 3D.

Pri využití 3D Objektov je možné zobrazenie porastov, budov a iných objektov do DMT. Objekty natočené k pozorovatel'ovi je možné umiestňovat' do DMT bud' jednotlivo alebo do zvolenej oblasti alebo pozdíž zvolenej línie [4].

\section{TVORBA DIGITÁLNEJ MAPY AREÁLU ZÁVODU}

\subsection{Realizácia zberu údajov}

Zber údajov bol realizovaný vo dvoch úrovniach, prvá - vybudovanie podrobného polohového a výškového bodového pol’a, druhá - meranie polohopisu a výškopisu. Predmetom zberu údajov a zobrazenia bola čast' areálu závodu (KÚ, Bratislava V) v rozsahu 11 ha. 


\subsection{Podrobné meranie polohopisu a výškopisu}

Priestorové súradnice potrebné pre tvorbu účelovej mapy boli určené prístrojom TOPCON GTS 6A $\mathrm{s}$ internou registráciou meraných údajov z bodov PPBP. Vzhl'adom na presnost' PPBP a presnost' použitého prístroja bola poloha meraných podrobných bodov určená s polohovou presnost'ou mxy = $0.04 \mathrm{~m}$ a výšky so strednou výškovou chybou $\mathrm{mh}=0.04 \mathrm{~m}$.

Výpočet súradníc a výšok podrobných bodov bol vykonaný v počítačovom prostredí pomocou programového vybavenia WIN KOKEŠ.

\section{TVORBA 3D MODELU}

\subsection{Príprava vstupných údajov}

Pre tvorbu DMT v uvedenej lokalite bolo potrebné pripravit' najprv vstupné údaje. Hlavným zdrojom údajov boli textové súbory z geodetických zápisníkov a výkresy vo formáte DXF. Základným zobrazením DMT je trojuholníková siet', ktorá vzniká generovaním. Generovanie nepravidelnej trojuholníkovej siete sa vykonáva v dvoch fázach.

Prvá fáza je generovanie prvotnej siete, jednotlivé body súboru sú postupne pripájané ku vznikajúcej trojuholníkovej sieti (obr. 1, [2]) tak, aby vznikal konvexný obal. V tejto fáze sa neberie ohl’ad na tvar trojuholníkov. V druhej fáze generovania sa zavedú do siete povinné spojnice. Siet’ je modifikovaná tak, aby body, ktoré sú uvedené v predpise povinných spojníc, boli spojené hranami siete.

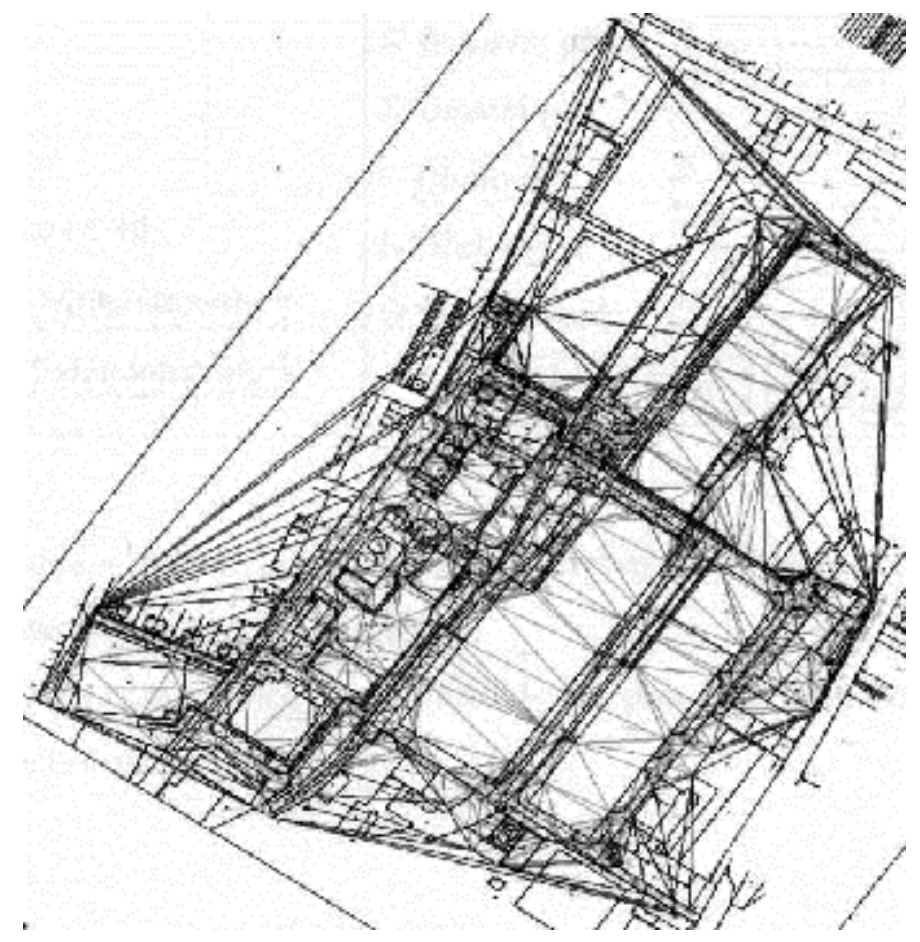

Obr. 1 Trojuholníková siet’-generovanie modelu z formátu DXF

\subsection{Príprava údajov pre objekty budov}

\subsubsection{Založenie výkresu a export objektov (budov)}

Po založení nového výkresu v hlavnom menu je potrebné vyberat' položku „Model - Nový model Založit i s půdorysem“ a z adresára DMT vyberat’ DMT uvedenej lokality. 
Pre možnost' „zhmotnenia“ vybraných objektov je potrebné v prvom rade vytvorit' nové hladiny, vyvolat' dialóg hladín „Objekty - Hladiny“ a vytvorit’ novú hladinu „steny“.

V importovanom výkrese si označíme vybraný objekt (budovu). Príkazom menu „Krajina - Spustit stěny“ (obr.2) ich vytvoríme. V menu „Krajina - Hladiny pro export stěn“ vyberieme hladiny „strechy“ a „steny“ a zadáme „Export“. Týmto príkazom sú objekty pripravené na zobrazenie budov [2].

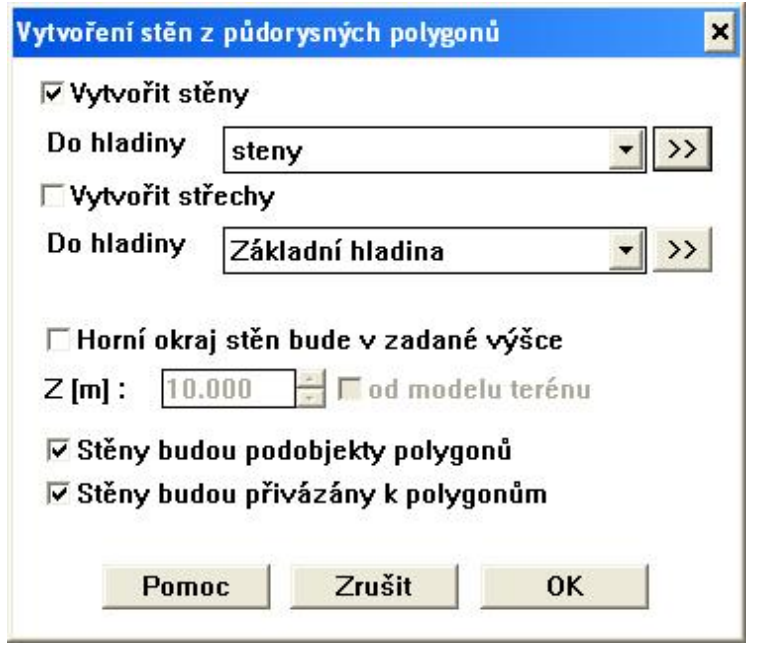

Obr. 2 Krajina - Spustit stěny - Vytvorenie stien z pôdorysných polygónov

\subsubsection{Individuálne textúry (fasády)}

Individuálne textúry nám poskytujú možnost’ na jednotlivé steny budov „prilepit““ skutočnú podobu daného objektu. Je ich možné získat fotografovaním a uložením do vhodného adresára.

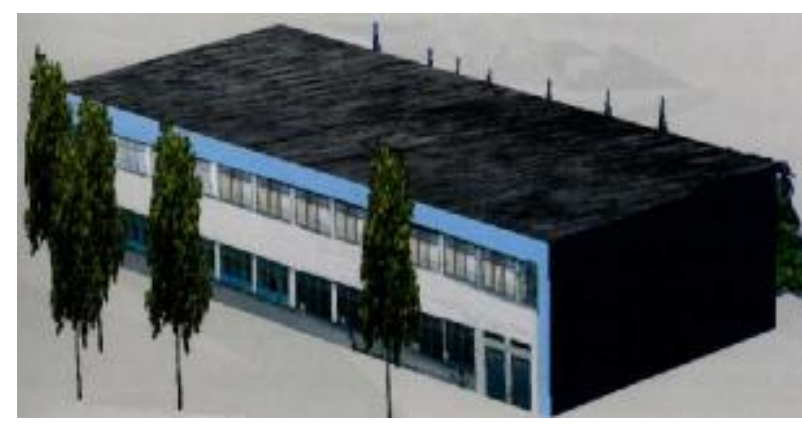

Obr. 3 Vytvorenie stien z fotografickej snímky
Pri tvorbe fasády vyberieme polygón steny, na ktorý chceme „prilepit"“ fasádu. Klepneme na neho pravým tlačidlom myši a v kontextovom okne vyberieme položku „Jmeno“. Tu vyplníme meno rastra (fasády), ktorý prislúcha danej stene. Postup opakujeme do vyčerpania pripravených fasád. V panely POGledov "Stěnové objekty“ vyberieme „Individuálni fasády“ a tu nalistujeme zložku s textúrami. Po potvrdení sa nám na stenách budov zobrazia individuálne textúry [2].

\subsubsection{Export objektov do krajiny}

Do scény (krajiny) možno vložit' pripravené 3D objekty - gul'a, valec, ihličnatý a listnatý strom, alebo je možné objekt nahradit' textúrou - fotografiou objektu (obr. 3). Môže to byt' napr. rastlina, lampa, lavička, postava. Každý typ objektu musí mat' svoju hladinu, ktorú si vytvoríme v programe Kres „Objekty - Hladiny“.

Pre vkladanie objektov do krajiny si vyberieme položku menu „Krajina - Vlož objekt pro POGledy“ (obr. 4). 


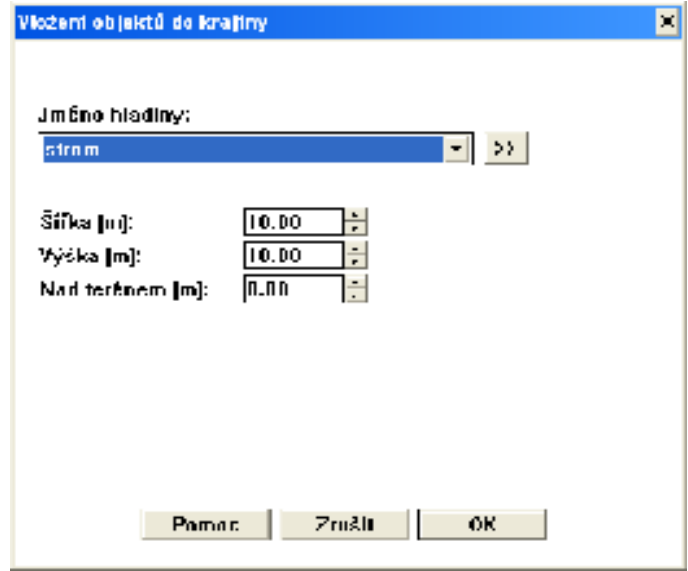

\section{Obr. 4 Vlož objekt pro POGledy - panel pre vkladanie objektov do krajiny}

V panely zadáme šírku a výšku objektu a umiestnime ho do pôdorysu. V prípade, že mienime vkladat' háj alebo alej stromov, teda viac rovnakých objektov naraz, nakreslíme v pôdoryse pomocou polygónu obrys hájika alebo trasu aleje. Potom polygón vyberieme a cez „Krajina - Vlož objekty pro POGledy do oblasti..." vložíme objekty do pôdorysu. Posledným bodom v príprave objektov do scény je „Krajina - Export objektov“ [2, 3, 4].

Po zvolení pohl’adu na scénu v POGledoch stlačíme tlačidlo $\$$. V panely „Bodové objekty“ (obr. 5) nastavíme spôsob zobrazenia typov objektov podla jednotlivých hladín.

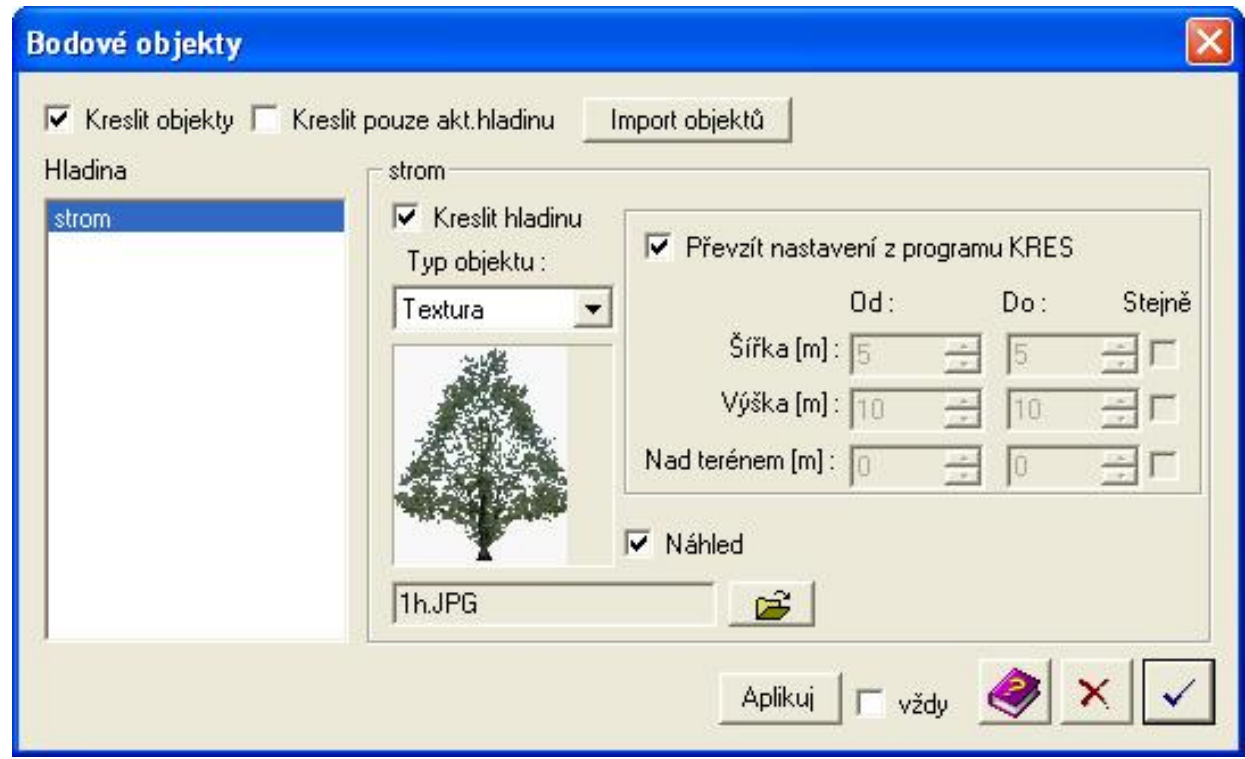

Obr. 5 Bodové objekty

\subsection{Príprava scény}

Vo výkrese, ktorý sme si pripravili vo výkresových súradniciach nakreslíme úsečku Táto úsečka predstavuje smer pohl'adu. Umiestnime ju preto tak, aby smerovala do miest, ktoré si chceme prehliadnut'. Vyvoláme ovládací panel menu „Krajina - 3D pohled na model“ (obr. 6) a nastavíme podl'a uváženia. Výsledný podhl'ad na čast' 3D modelu je na obr. 7, [2]. 


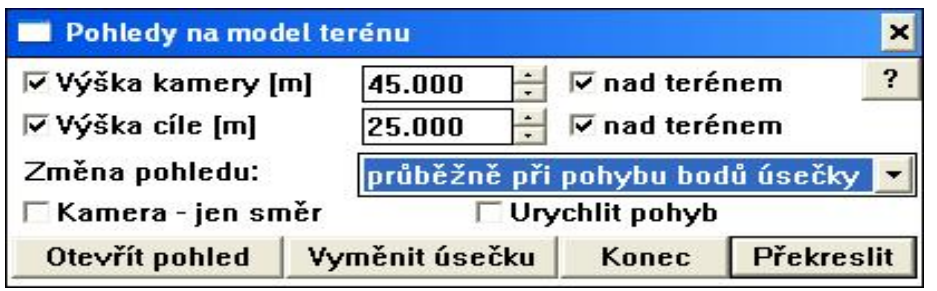

Obr. 6 3D- panel nastavenia pohl'adu na model terénu

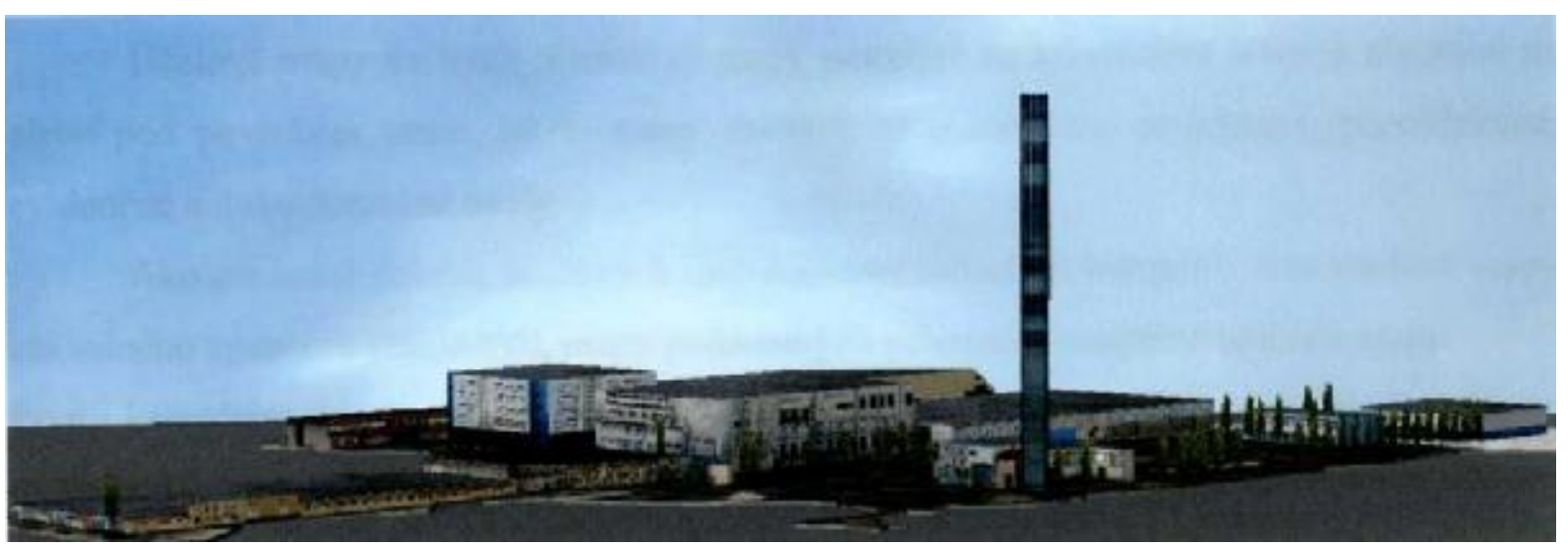

Obr. 7 3D pohl'ad na model

\section{ZÁVER}

Výsledok tvorby účelovej mapy môže byt' mapa grafická, číselná alebo digitálna. Trieda presnosti, mierka a v neposlednom rade aj obsah mapy vychádza z účelu, pre ktorý je mapa tvorená.

Pre oblast' projektovania, realizácie a rekonštrukcie stavebných objektov je výhodné využit' i prezentovaný softvér, ktorý umožňuje v prostredí PC riešit túto problematiku rýchlo a efektívne.

\section{Použitá literatura}

[1] SOKOL, Š.: Náležitosti geometrických plánov. Znalectvo, č. 2/2000, USI - TU Žilina, s.7-14.

[2] MIČEKOVÁ, E.: Geodetické práce pri tvorbe účelovej digitálnej mapy. Diplomová práca, Katedra geodézie SvF STU Bratislava, 2006, 58s.

[3] Podrobná užívatel'ská príručka softvéru Atlas.

[4] www.atlasitd.cz. 